\title{
Penggunaan Fungisida Nabati dalam Pembudidayaan Tanaman Pertanian
}

\author{
Stella D. Umboh ${ }^{1 *}$, Henny L. Rampe ${ }^{1}$ \\ 1Jurusan Biologi, Fakultas Matematika Dan Ilmu Pengetahuan Alam \\ Universitas Sam Ratulangi \\ *Penulis Korespondensi, Stella D. Umboh Jurusan Biologi FMIPA Universitas Sam Ratulangi Manado 95115. \\ Email: stellaumboh@unsrat.ac.id
}

\begin{abstract}
ABSTRAK
Kegiatan PKM ini dilatar belakangi oleh banyaknya petani yang menggunakan pestisida sintetik sebagai alternatif dalam mengendalikan hama dan penyakit tumbuhan yang ternyata memiliki residu yang dapat menimbulkan dampak negatif yang merugikan bagi lingkungan dan manusia. Salah satu alternatif yang mudah, efisien, murah, dan ramah lingkungan adalah dengan penggunaan fungisida nabati. Selama ini kelemahan umum yang dijumpai dikalangan petani adalah kurangnya pengetahuan mereka tentang penggunaan fungisida nabati sebagai salah satu solusi dalam pengendalian hama dan penyakit tumbuhan. Tujuan dan target khusus yang ingin dicapai pada kegiatan PKM ini adalah peningkatan pengetahuan dan ketrampilan petani dalam penggunaan fungisida nabati untuk mengurangi tingkat keracunan yang diakibatkan oleh pestisida sintetik dan peningkatan kesadaran lingkungan hidup bagi masyarakat di Desa Koka Kecamatan Tombulu Kabupaten Minahasa dari dampak samping yang ditimbulkan oleh pestisida bagi lingkungan dan kesehatan manusia. Untuk mengatasi permasalahan yang dihadapi petani tersebut, maka digunakan metode penyuluhan dan pelatihan penggunaan fungisida nabati untuk peningkatan produktifitas tanaman pertanian. Hasil Kegiatan PKM ini menunjukkan terjadinya peningkatan pemahaman peserta akan materi yang diberikan antara pretest (sebelum adanya kegiatan) dengan setelah kegiatan dilaksanakan (postest), dimana pada pretest peserta yang memiliki nilai kurang dari 50 berjumlah 27 orang (77.14\%) sedangkan pada postest menurun menjadi 1 orang $(2.85 \%)$ dan nilai lebih dari 50 pada pretest berjumlah 8 orang $(22.85 \%)$ sedangkan pada postest meningkat menjadi 34 orang (54.28\%). Berdasarkanhasilevaluasitopikbelajardarikegiatanpraktek, aspek pemahaman akan materi praktek adalah aspek dengan kriteria yang tertinggi dibandingkan aspek-aspek yang lainnya, dimana dari 35 orang, 22 orang (sangat baik), 8 orang (baik), 5 orang (sedang), dan untuk kategori kurang dan sangat kurang tidak adadari aktifitas kehidupan masyarakat sehari-hari di Desa Tosuraya Selatan Kecamatan Ratahan,seperti aktivitas rumah tangga, industri pengolahan hasil pertanian, peternakan,perkebunan, pertaniannaman pangan dan hortikultura didapati banyak sekali limbah khususnya limbah organik.
\end{abstract}

Kata kunci: Hama penyakit tumbuhan, Psetisida sintetik, Fungisida nabati, Pretest, Postest

\section{PENDAHULUAN}

\section{Analisis Situasi}

\section{A. Kondisi Mitra}

Koka adalah sebuah Desa di wilayah Kecamatan Tombulu, Kabupaten Minahasa, Sulawesi Utara, Indonesia (Anonim a, 2019). Kecamatan Tombulu yang keseluruhannya 8.525 ha $\left(85,25 \mathrm{~km}^{2}\right)$, dibagi menjadi delapan Desa (Anonim b, 2019). Kecamatan ini terbentuk sebagai hasil pemekaran dari 6 Desa yang mulanya berada di Kecamatan Pineleng dan 2 Desa dari Kecamatan Airmadidi. Letaknya pada ketinggian 200-500 m dpl. Kondisi tanah di kecamatan ini sebagian datar dan sisanya berbukit-bukit. Curah hujan rata-rata per tahunnya adalah 2.000-2.500 mm (Anonim a, 2019).

Lahan pertanian di Kabupaten Minahasa cukup strategis yaitu mencapai $75.000 \mathrm{Ha}$. Luas lahan sawah 5.500 Ha (Anonim c, 2019). Lahan di Kecamatan Tombulu digunakan untuk pemukiman (4397 ha), sawah (99 ha), perladangan (3.797 ha), alang-alang (197 ha), dan hutan lindung (35 ha) (Anonim a, 2019).

Besarnya lahan pertanian di Kelurahan Tombulu tersebut memungkinkan adanya penggunaan pestisida dalam rangka mengendalikan hama dan penyakit tumbuhan 
yang dewasa ini kerusakan yang ditimbulkan oleh hama dan penyakit tumbuhan dilahan-lahan pertanian sudah menjadi masalah yang serius di dunia pertanian. Berbagai upaya telah dilakukan untuk mengendalikan hama dan penyakit ini baik dengan cara tradisional maupun dengan cara modern yaitu penggunaan pestisida. Menurut Pattiselanno (2001) maka manusia sejak dahulu berusaha untuk mengurangi/menekan laju kerusakannya dengan menggunakan berbagai cara, baik yang bersifat tradisional maupun yang sudah modern yaitu pestisida. Demikian juga yang dilakukan banyak orang khususnya petani di Desa Koka Kecamatan Tombulu, mereka berusaha menekan ataupun mengurangi tingkat kerusakannya dengan pestisida.

Sampai saat ini kerusakan yang ditimbulkan oleh hama dan penyakit di lahanlahan pertanian sudah menjadi masalah yang serius didunia pertanian. Pada tahun permulaan program intensifikasi pangan, masalah hama dan penyakit diusahakan dengan penanganan secara kimiawi yakni menggunakan pestisida. Dibandingkan dengan teknik-teknik pengendalian hama dan penyakit lainnya, penggunaan pestisida oleh sebagian besar petani dianggap lebih efektif, penggunaannya lebih praktis, dan mendatangkan keuntungan ekonomi yang besar (Untung, 2006). Berbagai jenis pestisida telah digunakan sejak senyawa ini dikenal sebagai senjata ampuh untuk membasmi hama dan penyakit tanaman (Noya, 2004). Sejak diperkenalkan ke dalam dunia pertanian, pestisida (Herbisida, Fungisida, Insektisida, dll) telah menyebabkan produksi pertanian tergantung pada keandalannya selain pada penggunaan pupuk sintetik. Ketergantungan ini juga diperkuat dengan anggapan masyarakat khususnya petani bahwa tanpa menggunakan pestisida panen tidak menghasilkan apa-apa atau gagal sehingga pestisida menjadi "primadona" bagi petani.

Pengendalian penyakit dengan fungisida dan bakterisida sintetis oleh para petani selama ini tidak efektif dalam mengendalikan penyakit yang disebabkan oleh jamur patogen. Berbagai masalah yang ditimbulkan oleh jamur patogen merugikan bagi kehidupan manusia secara langsung maupun tidak langsung. Secara langsung dapat berupa residu yang melekat pada hasil tanaman dan secara tidak langsung akan mengganggu kesehatan konsumen, pencemaran lingkungan, serta membunuh organisme lainnya yang bukan sasaran (Arwiyanto, 2003 dalam Purwantisari et al., 2008).

Fenomena diatas menunjukkan betapa besarnya ketergantungan petani terhadap pestisida dan betapa besar resiko yang dihadapi petani dalam menggunakan pestisida. Keracunan pestisida dapat terjadi di kalangan petani di Desa Koka Kecamatan Tombulu diakibatkan karena cara penggunaannya yang sembarangan dan kurangnya pemahaman terhadap efek buruk yang ditimbulkannya. Petani dalam hal ini memiliki kedudukan ganda yaitu sebagai pelaku dan penderita keracunan pestisida.

Resiko keracunan pestisida di kalangan petani-petani Desa Koka Kecamatan Tombulu dapat diperkecil apabila diketahui alternatif pengendalian penyakit tanaman yang ramah lingkungan yaitu dengan menggunakan fungisida alami dari mikroba antagonis dan ekstrak tumbuhan. Penggunaan fungisida nabati selain dapat menghambat perkembangan penyakit juga aman bagi konsumen dan lingkungan karena mudah terurai dan tidak meninggalkan residu pada produk pertanian (Sudarmo, 2005), bahannya mudah didapat, dan harga relatif lebih murah (Dadang dan Ohsawa, 2000). Salah satu alternatif pengendalian terhadap benih adalah penggunaan fungisida nabati yang bersifat antifungal. Fungisida nabati mengandung senyawa bioaktif yang efektif menghambat atau mengendalikan patogen terbawa benih baik secara in vitro maupun in vivo (Eppler, 1995 dalam Halimursyadah et al., 2017).

Mitra yang akan dirangkul dalam kegiatan ini adalahpara petani yang mempunyai potensi dalam menggerakkan perekonomian keluarga yang bisa memiliki bekal pengetahuan dalam penggunaan pestisida secara terkendali untuk mengurangi tingkat keracunan yang diakibatkannya dalam rangka menanggulangi hama dan penyakit tumbuhan serta meningkatkan produksi pertanian kearah yang lebih baik lagi, dan dapat meningkatkan pengetahuan petani dalam menggunakan pestisida nabati yang ramah lingkungan. Oleh karena itu diperlukan adanya penyuluhan dan pelatihan penggunaan pestisida yang baik dan benar lewat pemanfaatan pestisida nabati untuk meningkatkan penggunaan pestisida yang ramah lingkungan.

\section{B. Peran Mitra dalam Lingkungan}

Masyarakat Desa Koka dalam hal ini petani merupakan kelompok masyarakat dengan 
jumlah paling banyak di lingkungannya sehingga keberadaan dan kegiatannya mempunyai pengaruh yang besar bagi perkembangan, peningkatan, dan pergerakkan perekonomian keluarga dan masyarakat Desa Koka, Kecamatan Tombulu, Kabupaten Minahasa. Keberadaan petani di Desa Koka menjadi tonggak kemandirian pertanian sehingga perputaran perekonomian di Desa Koka bisa terjadi.

\section{Permasalahan Mitra}

Salah satu pilar keberhasilan masyarakat terutama petani-petani Desa Koka, Kecamatan Tombulu, Kabupaten Minahasa dalam meningkatkan perekonomian keluarga dan masyarakat adalah peningkatan produksi pertanian dan dalam usaha mengatasi hama dan penyakit tumbuhan secara ramah lingkungan. Kelemahan yang dialami oleh masyarakatterutamapetani-petani Desa Koka Kecamatan Tombulu yaitu kurangnya pengetahuan mereka tentang dampak negatif dari penggunaan pestisida terhadap lingkungan terutama bagi kesehatan tubuh dan kurangnya pemahaman mereka tentang manfaat pestisida nabati.

Oleh karena itu bersama mitra akan dilaksanakan kegiatan untuk mengatasi kelemahan/ permasalahan yang dihadapi Mitra, dalam penggunaan pestisida nabati untuk mengurangi tingkat keracunan pestisida sintetik yang diakibatkannya.

\section{Tujuan dan Manfaat Kegiatan}

Tujuan dan manfaatyang ingin dicapai pada kegiatan PKM ini adalah peningkatan pengetahuan dan ketrampilan petani dalam penggunaan fungisi nabati untuk mengurangi tingkat keracunan yang diakibatkan oleh pestisida sintetik dan peningkatan kesadaran lingkungan hidup bagi masyarakat di Desa Koka Kecamatan Tombulu Kabupaten Minahasa dari dampak samping yang ditimbulkan oleh pestisida bagi lingkungan dan kesehatan manusia.

\section{METODE PELAKSANAAN}

\section{Sasaran kegiatan}

Sasaran kegiatan PKM ini adalah para masyarakat petani yang ada di Desa Koka, Kecamatan Tombulu, Kabupaten Minahasa.

\section{Lokasi kegiatan}

Kegiatan PKM ini dilaksanakan di Desa Koka Kecamatan Tombulu Kabupaten Minahasa. Kegiatan dilaksanakan dengan 2 tahap yaitu pemberian materi dan praktek pembuatan fungisida nabati.

\section{Metode yang digunakan :}

Adapun metode dalam penyelesaian solusi yang di tawarkan untuk mengatasi permasalahan kurangnya pengetahuan tentang pestisida dan dampak yang ditimbulkannya dan manfaat dari pestisida nabati, maka dilakukan penyuluhan dan pelatihan penggunaan pestisida nabati yang ramah lingkungan yang meliputi kegiatan:

1. Pemberian teori/ceramah, meliputi:

a. Tinjauan umum/pengertian pestisida.

b. Bahaya/efek samping pestisida sintetik terhadap lingkungan dan manusia

c. Tinjauan umum/pengertian pestisida nabati

d. Jenis-jenis pestisida nabati

e. Pengertian metabolit sekunder tanaman

f. Pengertian senyawa bioaktif

g. Manfaat pestisida nabati

2. Praktek Penggunaan Pestisida Nabati:

a. Pembuatan Pestisida Nabati: Daun Jeruk,

Daun Sirsak, dan Daun Cengkih

- Maserasi

- Ekstrak kasar pestisida nabati

b. Pengujian pestisida nabati secara invitro

- Metode Umpan Beracun

- Metode Kertas Saring

\section{HASIL DAN PEMBAHASAN}

Adapun hasil kegiatan yang diperoleh adalah sebagai berikut :

A. Produk/ kegiatan yang dinilai bermanfaat dari berbagai perspektif:

Dalam kegiatan ini, produk kegiatan yang dihasilkan berupa peningkatan pengetahuan serta ketrampilan mitra tentang penggunaan 
Tabel 1. Hasil Test Awal (Pretest) Peserta Penyuluhan/

Pelatihan Penggunaan Fungisida Nabati

\begin{tabular}{|c|c|c|c|}
\hline No & $\begin{array}{c}\text { Interval } \\
\text { Nilai }\end{array}$ & $\begin{array}{c}\text { Jumlah } \\
\text { (Orang) }\end{array}$ & $\%$ \\
\hline 1 & $0-10$ & 8 & 22.86 \\
\hline 2 & $11-20$ & 10 & 28.58 \\
\hline 3 & $21-30$ & 5 & 14.28 \\
\hline 4 & $31-40$ & 2 & 5.71 \\
\hline 5 & $41-50$ & 2 & 5.71 \\
\hline 6 & $51-60$ & 8 & 22.86 \\
\hline 7 & $61-70$ & 0 & 0.00 \\
\hline 8 & $71-80$ & 0 & 0.00 \\
\hline 9 & $81-90$ & 0 & 0.00 \\
\hline 10 & $91-100$ & 0 & 0.00 \\
\hline & Jumlah & 35 & 100.00 \\
\hline
\end{tabular}

2. Pelaksanaan postest (tes akhir)

Keberhasilan dari kegiatan PKM ini dipantau dari hasil postest yang diberikan. Soal yang diberikan sama dengan yang diberikan pada kegiatan pretest dengan soal pilihan berganda berjumlah 10 soal yang dikerjakan selama 15 menit, yang diberikan pada 35 orang peserta. Dari hasil postest yang diperoleh ternyata ada 13 peserta yang mendapat nilai tertinggi pada interval nilai 61-70 (37.15\%), dan terendah sebanyak 1 orang saja pada interval nilai 41-50 $(2.85 \%)$ (Tabel 2). Dari rata-rata nilai postest dapat dilihat kenaikan yang signifikan, dilihat dari nilai kecil dari 50 hanya berjumlah 1 orang peserta saja $(2.85 \%)$. Hasil analisis menunjukkan bahwa terdapat peningkatan pemahaman dan ketrampilan dari para peserta berdasarkan nilai pretest dan postetst (Tabel 3).

Dari Tabel 3 di bawah ini menunjukkan bahwa terjadi kenaikan pemahaman sebesar $54.28 \%$. Berdasarkan hasil analisis ini menandakan bahwa materi yang diberikan dapat dimengerti dan dipahami oleh peserta penyuluhan dan pelatihan penggunaan fungisida nabati ini.

Tabel 2. Hasil Test Akhir (Postest) Peserta Penyuluhan/

Pelatihan Penggunaan Fungisida Nabati 


\begin{tabular}{|c|c|c|c|}
\hline No & $\begin{array}{c}\text { Interval } \\
\text { Nilai }\end{array}$ & $\begin{array}{c}\text { Jumlah } \\
\text { (Orang) }\end{array}$ & $\%$ \\
\hline 1 & $0-10$ & 0 & 0.00 \\
\hline 2 & $11-20$ & 0 & 0.00 \\
\hline 3 & $21-30$ & 0 & 0.00 \\
\hline 4 & $31-40$ & 0 & 0.00 \\
\hline 5 & $41-50$ & 1 & 2.85 \\
\hline 6 & $51-60$ & 3 & 8.57 \\
\hline 7 & $61-70$ & 13 & 37.15 \\
\hline 8 & $71-80$ & 7 & 20.00 \\
\hline 9 & $81-90$ & 3 & 8.57 \\
\hline 10 & $91-100$ & 8 & 22.86 \\
\hline & Jumlah & 35 & 100.00 \\
\hline
\end{tabular}

Tabel 3. Nilai Pretest Dan Postest Peserta Penyuluhan/Pelatihan Penggunaan Pestisida

\begin{tabular}{|c|c|c|c|c|c|}
\hline \multirow{2}{*}{$\begin{array}{l}\mathbf{N} \\
\mathbf{0}\end{array}$} & \multirow{2}{*}{$\begin{array}{c}\text { Interva } \\
\quad\end{array}$} & \multicolumn{2}{|c|}{ Pretest } & \multicolumn{2}{|c|}{ Postest } \\
\hline & & $\underset{\mathbf{I}}{\mathbf{J m}}$ & $\%$ & $\underset{\mathbf{l}}{\mathbf{J m}}$ & $\%$ \\
\hline 1 & $0-10$ & 8 & 22.86 & 0 & 0.00 \\
\hline 2 & $11-20$ & 10 & 28.58 & 0 & 0.00 \\
\hline 3 & $21-30$ & 5 & 14.28 & 0 & 0.00 \\
\hline 4 & $31-40$ & 2 & 5.71 & 0 & 0.00 \\
\hline 5 & $41-50$ & 2 & 5.71 & 1 & 2.85 \\
\hline 6 & $51-60$ & 8 & 22.86 & 3 & 8.57 \\
\hline 7 & $61-70$ & 0 & 0.00 & 13 & 37.15 \\
\hline 8 & $71-80$ & 0 & 0.00 & 7 & 20.00 \\
\hline 9 & $81-90$ & 0 & 0.00 & 3 & 8.57 \\
\hline 10 & $91-100$ & 0 & 0.00 & 8 & 22.86 \\
\hline & ımlah & 35 & $\begin{array}{c}100.0 \\
0\end{array}$ & 35 & $\begin{array}{c}100.0 \\
0\end{array}$ \\
\hline
\end{tabular}

Dilihat dariperbandingan nilai pretest dan postest yang disajikan dalam Gambar 1 di bawah ini, memperlihatkan tidak terdapatnya peserta yang memiliki nilai di bawah 40 pada nilai postest $(0,00 \%)$ dari interval nilai $0-40$, dibandingkandengansewaktupesertabelumdiberi kan penyuluhan dan pelatihan (pemberian materi), rata-rata nilai pretest pada interval nilai $0-40$ sebesar $71.43 \%$. Hal ini menunjukkan bahwa kegiatan yang diberikan benar-benar dapat meningkatkan pengetahuan dan pemahaman peserta terhadap penggunaan fungisida nabati.

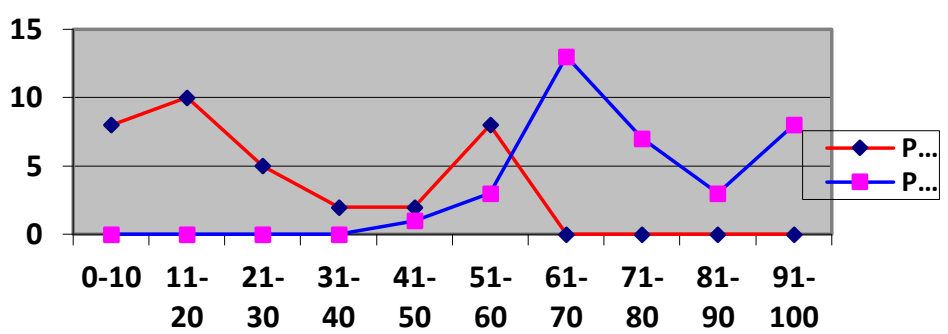

Gambar 1.PerbandinganNilai Pretest Dan Postest

3. Praktek pembuatan fungisida nabati (ekstrak daun pepaya, sirsak, dan cengkih)

Metode yang digunakan yaitu memperagakan cara-cara pembuatan ekstrak daun pepaya, sirsak, dan cengkih untuk dijadikan fungisida nabati. Peserta diperkenalkan terlebih dahulu tentang tinjauan umum/pengertian pestisida, bahaya/efek samping pestisida sintetik terhadap lingkungan dan manusia, tinjauan umum/pengertian pestisida nabati, jenis-jenis pestisida nabati, pengertian metabolit sekunder tanaman, pengertian senyawa bioaktif, dan manfaat pestisida nabati. Kemudian peserta diberikan pelatihan tentang pembuatan pestisida nabati dari daun jeruk, daun sirsak, dan daun cengkih (untuk mendapatkan metabolit sekunder/senyawa bioaktif dari tanaman tersebut). Langkah yang dilakukan terlebih dahulu yaitu maserasi dan pembuatan ekstrak kasar pestisida nabati. Setelah didapatkan larutan fungisida nabati dari ketiga jenis tanaman tersebut, maka dilakukan pengujian secara invitro yaitu dengan menggunakan metode umpan beracun dan metode kertas saring.

Agar peserta lebih memahami cara pembuatan fungisida nabati ini maka salah seorang dari peserta dimintakan untuk mempraktekkan cara pembuatan fungisida nabati secara benar. Untuk mengukur sejauh mana peserta dapat menyerap materi praktek ini maka setiap peserta dimintakan untuk mengisi lembar evaluasi topik belajar disetiap selesai pemberian materi praktek. Lembar evaluasi topik belajar seperti pada Tabel 4.

Tabel 4.LembarEvaluasiTopikBelajar 
Rekapan evaluasi topik belajar selama praktek berlangsung memperlihatkan hasil bahwa tingkat pemahaman petani tentang materi bagaimana cara pembuatan fungisida nabati sangat tinggi, ternyata dari 35 orang, 22 orang (sangat baik), 8 orang (baik), 5 orang (sedang), dan untuk kategori kurang dan sangat kurang tidak ada. Untuk kesesuaian materi dengan kebutuhan peserta, yang memiliki kriteria sangat baik ada 21 orang, baik (7 orang), sedang (2 orang), kurang (5 orang), dan sangat kurang tidak ada. Untuk aspek motivasi peserta terhadap praktek yang dilakukan, setelah diukur hasilnya memperlihatkan bahwa dari 35 orang yang mengikuti praktek, ternyata ada 23 orang (sangat baik), 5 orang (baik), 7 orang (sedang), dan yang kurang, serta sangat kurang tidak ada. Dari hasil analisis juga memperlihatkan bahwa kemampuan peserta mengkomunikasikan materi pelatihan dengan orang lain sangatlah besar, yang memiliki kriteria sangat baik (18 orang), baik (15 orang), dan sedang (2 orang). Sedangkan keinginan peserta berkomunikasi dengan pemandu tentang materi yang diberikan termasuk kriteria yang sangat rendah, ini dibuktikan dengan sedkitnya peserta yang memiliki kriteria sangat baik (17 orang), baik dan sedang (8 orang), dan kurang (2 orang). Secara keseluruhan hasil analisis evaluasi topik belajar peserta dapat dilihat pada Tabel 5 dan Gambar 2 di bawah ini.

Dari Tabel 5 dan Gambar 2 di bawah ini terlihat bahwa aspek pemahaman akan materi praktek adalah yang tertinggi kriterianya dibadingkan aspek-aspek yang lainnya. Hal ini disebabkan karena peserta sangat aktif dalam mengikuti praktek, ditandai dengan semangat dan antusias peserta dengan rasa ingin tahu yang tinggi akan materi terbukti dengan banyaknya pertanyaan yang muncul dalam sesi diskusi/tanya jawab. Selain itu pula motivasi peserta sangat besar juga yang ditunjang dengan kemampuan yang besar dalam mengkomunikasikan materi praktek kepada orang lain bahkanpun dalam berkomunikasi dengan pemandu. 

(Praktek)

\begin{tabular}{||c|c|c|c|c|c||}
\hline \hline & \multicolumn{5}{|c|}{ Total Kriteria } \\
\cline { 2 - 6 } & & & & & \\
\cline { 2 - 6 } & $\begin{array}{c}\text { SangatK } \\
\text { urang }\end{array}$ & $\begin{array}{c}\text { Kur } \\
\text { ang }\end{array}$ & $\begin{array}{c}\text { Sed } \\
\text { ang }\end{array}$ & $\begin{array}{c}\text { Ba } \\
\text { ik }\end{array}$ & $\begin{array}{c}\text { Sangat } \\
\text { Baik }\end{array}$ \\
\hline 1 & 0 & 0 & 5 & 8 & 22 \\
\hline 2 & 0 & 5 & 2 & 7 & 21 \\
\hline 3 & 0 & 0 & 7 & 5 & 23 \\
\hline 4 & 0 & 0 & 2 & 15 & 18 \\
\hline 5 & 0 & 2 & 8 & 8 & 17 \\
\hline
\end{tabular}

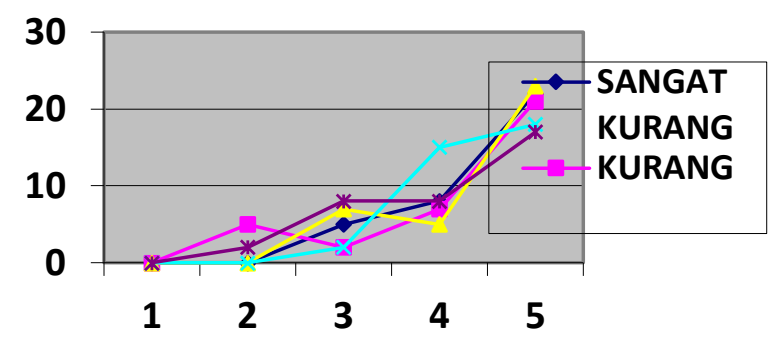

Gambar 2. Hasil Keseluruhan Rekapan Evaluasi Topik Belajar

Keterangan:

1. Pemahamanan terhadap materi praktek yang disampaikan pemandu

2. Kesesuaian materi praktek dengan kebutuhan anda

3. Motivasi anda menindaklanjuti semua petunjuk sesuai pelatihan di Desa anda

4. Kemampuan anda mengkomunikasikan hasil praktek pembuatan fungisida nabati dengan pihak lain

5. Keinginan anda berkomunikasi dengan pemandu tentang materi praktek pembuatan fungisida nabati ini

B. Evaluasi Kinerja Program

1. Indikator Kinerja

(a) Dokumentasi proses:

Model grafik (kerangka) dan materi yang diajukan dalam penanganan permasalahan mitra berupa gambaran Ipteks yang ditransfer kepada mitra adalah sebagai berikut (Gambar 3):

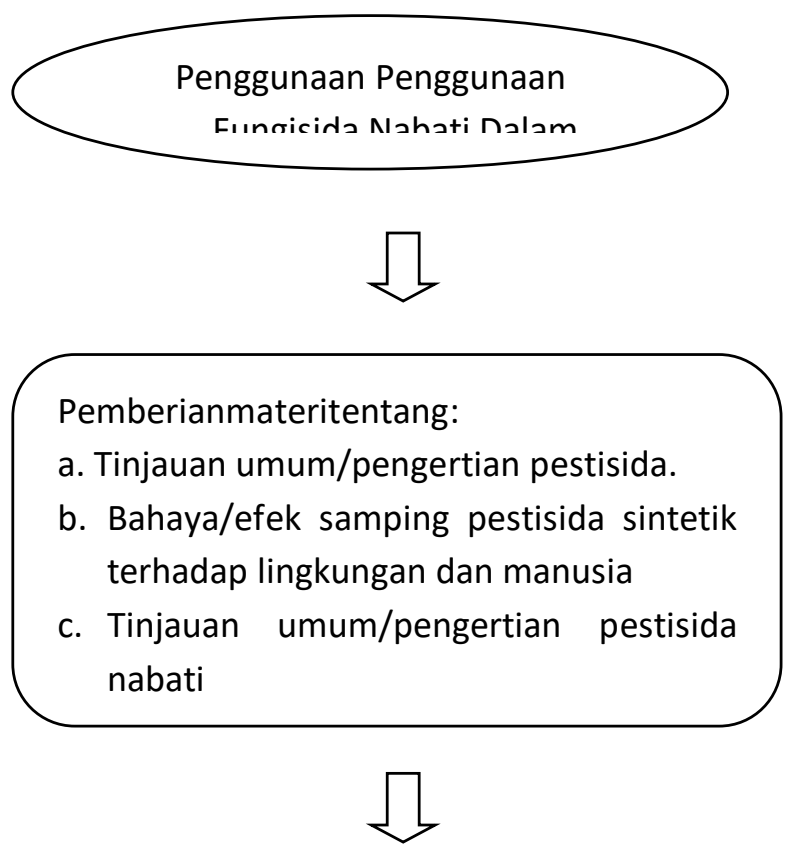

Praktek Penggunaan Pestisida :

a. a. Pembuatan Pestisida Nabati: Daun Jeruk, Daun Sirsak, dan Daun Cengkih - Maserasi

- Ekstrak kasar pestisida nabati

b. Pengujian pestisida nabati secara invitro - Metode Umpan Beracun

Gambar 3. Gambaran Ipteks Yang Ditransfer Kepada Mitra

Materi di atas diberikan pada 35 orang peserta selama 120 menit dengan menggunakan metode ceramah, diskusi, dan praktek. Pemberian materi dilakukan dengan menggunakan alat bantu LCD dan Laptop. Peserta kegiatan PKM ini diikuti oleh masyarakat, PNS, dan pemerintah setempat.

Dalam pemberian materi dan praktek, banyak peserta yang mengajukan pertanyaan, sharing pengalaman, dan pendapat. Ada beberapa pertanyaan yang muncul disaat praktek dilaksanakan, diantaranya: 
1. Untuk apa daun pepaya digunakan dalam praktek kali ini?, saya tahu daun pepaya adalah obat untuk menurunkan darah tinggi.

2. Apakah tanaman sirsak bisa juga digunakan dalam mengobati penyakit yang diderita manusia?.

3. Mengapa harus menggunakan Mixer?.

4. Apakah daun-daun yang digunakan tadi bisa mengendalikan penyakit pada tanaman?

5. Saya mempunyai pengalaman bahwa daun cengkih bisa mengobati sakit gigi, dan saya dengar juga bahwa daun ini bermanfaat dalam mengendalikan hama dan penyakit tanaman terutama minyak cengkihnya, apakah bisa seperti itu?.

(b) Impact factor (keberlanjutan kegiatan atau ketepatan solusi)

1. Deskripsi secara sistematik keberlanjutan usaha dan/atau perilaku mitra, termasuk analisis kebutuhannya

Program ini sangat dibutuhkan oleh masyarakat khususnya petani di areal perkebunan atau tanaman pertanian, terutama dalam mengurangi tingkat keracunan yang diakibatkan oleh adanya residu pestisida sintetik. Sebagai masyarakat yang berprofesi sebagai petani tentu mempunyai aktivitas yang pasti selalu bersentuhan langsung dengan pestisida di perkebunan/di areal pertanian, tentu kegiatan PKM tentang penggunaan fungisida nabati sangat diperlukan oleh masyarakat sebagai petani dalam mengurangi resiko keracunan pestisida atau meminimalisir dampak dari residu pestisida sintetik dan menerapkan program pemerintah dalam sustainable lingkungan (penggunaan pestisida yang ramah lingkungan).

Kegiatan ini akan dilanjutkan oleh Petani, Aparat Desa, Tokoh Masyarakat, dan Agama yaitu dengan mensosialisasikan penggunaan pestisida dan dampak negatif yang ditimbulkan oleh residu pestisida tersebut bagi lingkungan dan manusia kepada seluruh komponen masyarakat. Aparat Desa, Tokoh Masyarakat dan Agama juga dapat mengajak seluruh masyarakat dalam hal ini petani untuk menggunakan pestisida yang ramah lingkungan/bijaksana dengan menggunakan pestisida berbahan alami seperti halnya fungisida nabati. Diharapkan dari keberlanjutan program ini oleh Aparat Desa, Tokoh Masyarakat, dan Agama maka pengenalan terhadap pestisida dapat dipahami oleh masyarakat/petani dan penggunaan fungisida nabati sebagai pestisida yang ramah lingkungan/bijaksana akan tetap terjaga.

2. Ketepatan sekaligus keterbatasan dari solusi yang diterapkan dalam penanganan permasalahan mitra lewat aktivitas P2M yang dikerjakan.

Keterbatasan dari kegiatan dalam penanganan permasalahan mitra adalah sebagai berikut:

1. Kurangnya pengetahuan masyarakat/petani akan dampak negatif dari penggunaan pestisida terhadap lingkungan dan kesehatan manusia.

2. Tingkat pendidikan petani yang sebagian besar masih pada taraf SD dan SMP.

3. Ketersediaan petunjuk/pedoman penggunaan fungisida nabati sebagai salah satu pestisida alami yang ramah lingkungan belum dipajang di papan informasi Desa dan ditempat-tempat umum yang biasanya dihadiri masyarakat/petani.

4. Akses terhadap internet belum dipergunakan sehingga informasi terhadap pestisida dan dampak yang ditimbulkannya sangat jarang diperoleh petani.

5. Dampak negatif dan bahaya penggunaan pestisida sintetik masih sedikit di sosialisasikan ke masyarakat Desa.

\section{KESIMPULAN DAN SARAN}

Hasil Kegiatan PKM ini menunjukkan terjadinya peningkatan pemahaman peserta akan materi yang diberikan antara pretest (sebelum adanya kegiatan) dengan setelah kegiatan dilaksanakan (postest), dimana pada pretest peserta yang memiliki nilai kurang dari 50 berjumlah 27 orang $(77.14 \%)$ sedangkan pada posttest menurun menjadi 1 orang $(2.85 \%)$ dan nilai lebih dari 50 pada pretest berjumlah 8 orang $(22.85 \%)$ sedangkan pada posttest meningkat menjadi 34 orang $(54.28 \%)$. Berdasarkan hasil evaluasi topic belajar dari kegiatan praktek, aspek pemahaman akan materi praktek adalah aspek dengan kriteria yang tertinggi dibandingkan aspek-aspek yang lainnya, dimana dari 35 orang, 22 orang (sangat baik), 8 orang (baik), 5 orang (sedang), dan untuk kategori kurang dan sangat kurang tidak ada. 
Saran yang bisa dikemukakan dalam kegiatan PKM ini yaitu sebaiknya penggunaan fungisida nabati sebagai alternatif pengendalian hama dan penyakit tanaman yang ramah lingkungan terus disosialisasikan kepada masyarakat luas oleh pemerintah Desa mengingat manfaat dari fungisida nabati ini sangatlah besar bagi pengembangan tanaman pertanian.

\section{UCAPAN TERIMAKASIH}

Tim penulis ingin mengucapkan terimakasih kepada Pimpinan Universitas Sam Ratulangi Manado, Pimpinan LPPM Unsrat Manado, yang telah mendanai kegiatan ini melalui Skim Program Kemitraan Masyarakat (PKM) dana PNBP tahun anggaran 2019.

\section{DAFTAR PUSTAKA}

Anonim a, 2019.Koka, Tombulu, Minahasa. Wikipedia.https://id.wikipedia.org/wik i/Koka,_Tombulu,_Minahasa $<01 / 03 / 2019>$.

Anonim b, 2019.Tombulu, Minahasa.Wikipedia. https://id.wikipedia.org/wiki/Tombulu, _Minahasa <01/03/2019>.

Anonim c, 2019.Potensi Lahan Pertanian di Minahasa Masih Strategis. Klik Net News.http://www.kliknews.net/2019/0 2/09/lahan-pertanian-di-minahasamasih-strategis/ <01/03/2019>.

Dadang dan Ohsawa, K. 2000. Penghambatan aktivitas makan larva Plutellaxylostella (L).(Lepidoptera: Yponomeutidae) yang diperlakukan ekstrak biji Swietenia mahogany JACQ (Meliaceae). Bul. Hama dan Penyakit Tumbuhan. 1:27-32.

Halimursyadah, Syamsuddin, H. A. Putri. 2017. Efektivitas Fungisida Nabati dalam Menghambat Aktivitas Seed Born Pathogen pada Benih Tomat secara in Vitro. Prosiding Seminar Nasional Pascasarjana (SNP )Unsyiah, April 13, 2017, Banda Aceh, Indonesia.
Noya, A.I. 2004. Residu Insektisida Profenofos Pada Sayuran Kubis Dan Tanah Andosol Rurukan Kecamatan Tomohon. Tesis. Program PascaSarjana Universitas Samratulangi Manado.

Pattiselanno, A.E. 2001. Analisis Sikap dan Perilaku Terhadap Sasi Pada Masyarakat Pulau Saparua Kabupaten Maluku Tengah. Eugenia. 7(4) : 282288.

Purwantisari S, R.S. Ferniah, dan B. Raharjo. 2008. Pengendalian Hayati Penyakit Lodoh (Busuk Umbi Kentang) Dengan Agens Hayati Jamur-Jamur Antagonis Isolat Lokal. Bioma. 10(2): 13-19.

Sudarmo, S. 2005. Pestisida Nabati: Pembuatan dan Pemanfaatannya. Kanisius, Yogyakarta.

Untung, K. 2006. Pengantar Pengelolaan Hama Terpadu (edisi kedua). Penerbit Gadjah Mada University Press. Yogyakarta. 